University of Nebraska - Lincoln

DigitalCommons@University of Nebraska - Lincoln

$4-21-2020$

\title{
CARES Act 2020: Unemployment Insurance and Farmer/Ranchers
}

\author{
Robert Tigner \\ University of Nebraska-Lincoln, Robert.tigner@unl.edu
}

Follow this and additional works at: https://digitalcommons.unl.edu/ageconfarmmgmt

Part of the Agribusiness Commons, Agriculture Law Commons, Entrepreneurial and Small Business Operations Commons, Management Information Systems Commons, Other Business Commons, and the Other Economics Commons

Tigner, Robert, "CARES Act 2020: Unemployment Insurance and Farmer/Ranchers" (2020). Extension Farm and Ranch Management. 26.

https://digitalcommons.unl.edu/ageconfarmmgmt/26

This News Article is brought to you for free and open access by the Agricultural Economics Department at DigitalCommons@University of Nebraska - Lincoln. It has been accepted for inclusion in Extension Farm and Ranch Management by an authorized administrator of DigitalCommons@University of Nebraska - Lincoln. 


\section{CARES Act 2020: Unemployment Insurance and Farmer/Ranchers}

\section{By Robert Tigner}

April 21, 2020

Generally, unemployment insurance across the country is managed by state government. Each has different rules, with oversight by the US Department of Labor. The Coronavirus Aid, Relief, and Economic Security Act (CARES) Act made changes to the unemployment coverage for workers and appropriated funds for the changes. The act tasked the Labor Department with writing rules for the changes and it has issued an Unemployment Insurance Letter - UL No. 16-20 - that begins the rulemaking process. This guidance will then be used by Nebraska to implement the CARES Act. This article reviews what is known now with future rules to clarify eligibility.

\section{Changes to Unemployment Insurance}

Several changes were made to unemployment insurance, including eligibility, length of coverage and benefits. These include:

1. An additional $\$ 600$ weekly in benefits from federal appropriations until no later than July 31 , 2020.

2. Increase in the length of unemployment benefits to 39 weeks.

3. Creation of the temporary program, Pandemic Unemployment Assistance (PUA), which expanded eligibility. Eligible persons include self-employed, those seeking part-time employment and those with insufficient work history for benefits.

The Labor Department currently has a permanent Disaster Unemployment Assistance (DUA) program that makes unemployment payments during a disaster to self-employed persons. This includes farmers and ranchers in the definition of self-employed. The department says the new temporary pandemic assistance will be administered like the Disaster Unemployment Assistance Program. So, one can expect that farmers will be eligible under the Pandemic Unemployment Assistance Program.

\section{Pandemic Unemployment Assistance Program: Rules for Unemployment Assistance}

Eligibility for PUA comes when an individual is ineligible or has exhausted regular unemployment benefits. The individual may also have to exhaust the CARES Act's new Pandemic Emergency Unemployment Compensation (PEUC) program. The Person must be unemployed (fully or partially), unavailable or unable to work due to COVID-19. The Labor Department has provided a list of situations where PUA would apply, although the list is not exhaustive. When the CARES Act created PUA, it also created a general category that leaves room for the Labor Department to add situations not yet considered. Criteria that give someone PUA eligibility are: 
1. Individual has COVID-19.

2. Household member has COVID-19.

3. Primary caregiver of household member is unable to go to a school or facility closed due to COVID-19.

4. Unable to work due to quarantine.

5. Unable to go to work due to self-quarantine.

6. Became sole income source if household head died due to COVID-19.

7. Place of employment closed due to COVID-19.

8. Quit job due to COVID-19. This criterion means that the individual has or had COVID-19.

9. Scheduled for work but could not reach the work site.

10. Additional criteria. The Labor Department has authority to create criteria not envisioned above.

The Nebraska Department of Labor website (https://dol.nebraska.gov/UIBenefits) has resources explaining unemployment insurance and explains how to apply for it. The site also explains when to expect benefits to start after application, which is usually no more than 21 days but may take longer due a large volume of applications. The state has received guidance on two of the three CARES benefits and is creating the programs with the guidance received. Once an individual applies for unemployment insurance, they need not apply for the $\$ 600$ added benefit since it will automatically be paid. The $\$ 600$ benefit will be retroactively paid to March 29, 2020. Regular unemployment benefits are not paid for weeks prior to filing, so filing as soon as possible is necessary. Self-employed individuals - presumably farmers and ranchers - will have their applications reviewed for eligibility.

Sources:

Farmers' Guide to COVID-19 Relief. (2020, April 15). FLAG. http://www.flaginc.org/2020/04/farmersguide-to-COVID-19-relief/

Official Nebraska Department of Labor | Unemployment Insurance Benefits_File Online at NEworks.nebraska.gov. (n.d.). Retrieved April 17, 2020, from https://dol.nebraska.gov/UIBenefits

Robert Tigner is an agricultural systems economist and extension educator in The Department of Agricultural Economics. 